\title{
Rooting dynamics of Brazilian cherry tree minicuttings
}

\author{
Geniane Lopes Carvalho Ozelame ${ }^{1}$, Luana Borges Affonso', Thaís Helena Cappellaro', Márcia Wulff \\ Schuch$^{1}$, Zeni Fonseca Pinto Tomaz ${ }^{1, *}$
}

${ }^{1}$ Universidade Federal de Pelotas, Programa de Pós-Graduação em Agronomia, Fruticultura de Clima Temperado, Departamento de Fitotecnia, Caixa Postal 354, CEP 96010-900 Pelotas, RS, Brazil. Corresponding author, E-mail: zfptomaz@yahoo.com.br

\begin{abstract}
The expansion of Brazilian cherry tree cultivation is affected by propagation difficulties and slow seedling production development. The cuttings and minicuttings technique is an alternative that offers several advantages, and it proved to be highly promising for many fruit tree species. Minicuttings taken from a clonal garden were rooted in $22 \times 14 \times 10 \mathrm{~cm}$ plastic boxes containing vermiculite, at IAB concentration of $2.000 \mathrm{mg} \cdot \mathrm{L}^{-1}$. The experimental design was totally randomized with eight treatments (cultivation weeks), with four replications, with five minicuttings each. They were evaluated eight times (once a week), for a period of two months. The following variables were analyzed: number of swollen minicuttings, rooted minicuttings and minicuttings with roots longer than $1 \mathrm{~cm}$. From the third week onwards, rooting was positive, with $70 \%$ of rooted minicuttings and 5\% with swellings. In the fourth evaluation, 55\% already showed roots longer than one centimeter, with a mean of $2.66 \mathrm{~cm}$, five with roots emergence and three with swellings. In general, in seven weeks' time the minicuttings showed efficient root development and were ready to be transplanted to plastic bags to develop quality seedlings.
\end{abstract}

Key words: Seedlings production, rooting dynamics, minicutting, Eugenia uniflora (L).

\section{INTRODUCTION}

Despite its relatively low production compared to other cultures, Brazilian cherry tree culture shows great expansion potential, since it is a fruit used for many purposes. Growers use Brazilian cherry for its versatility, since, besides being used in cosmetology, it is also used for making jams, sweets, ice creams, liqueurs and wines of considerable quality (Scalon et al., 2001).

To increase production of this culture, the development of quality seedlings and other factors that affect rooting process should be taken into careful consideration. During the rooting process, the anatomy of adventitious roots involves the development of groups of meristematic cells, the differentiation of these cell groups into root primordia, and the development and emergence of new roots, including the rupture of stem roots and the development of vascular connections with cutting conducting tissues (Hartmann et al., 2002).

Factors that affect rooting may be classified into internal or endogenous factors, considering mainly the physiological conditions and root plant age, cutting collection period, rooting genetic potential, sanity, hormonal balance, phenolic compound oxidation and cutting position in the branch and external or exogenous such as temperature, lighting, humidity and substrate (Fachinello et al., 1995). Endogenous factors constitute one of the most serious problems, which require the search for additional techniques, such as the use of growth regulators to promote rooting improvement (Biasi 1996; Mayer 2001; Pio et al., 2005).

In regards to vegetative material storage, the time between collection-preparation and minicuttings sowing in the substrate deserves special attention. Ferrari et al. (2004), for instance, recommend less than 15 minutes intervals; however, for greater shoot collection distances, great number of seedlings (Alfenas et al., 2004) and some working interval times, the storage of vegetative propagules for longer periods is necessary.

Considering that most companies from the Brazilian forestry sector uses the presence of roots on the core base as criteria for removing seedlings from the greenhouse during eucalyptus clones minicuttings rooting process, it is possible to demonstrate that normally there is a tendency to overestimate rooting greenhouse permanence time to induce rooting process. (Ferreira et al., 2004).

This overestimation may also occur during the rooting of fruit tree species. Many times, growers decide to transplant minicuttings before they are ready and the root system is well developed. This may bring several problems to the nutrients balance, causing plant death.

The minicutting technique is used with several crops of great economic importance and several fruit tree species such as the guava (Psidium guajava) (Altoé and Marinho 2012), plum (Prunus salicina) (Tonietto et al., 2001), soursop (Annona muricata) (Figueirêdo et al., 2013) yellow passion fruit (Passiflora edulis f, Flavicarpa) (Carvalho et al., 2007), peach (Prunus persica) (Tomaz et al., 2014) and olive trees (Olea europaea) (Cappellaro 2013). They have all shown satisfactory results regarding seedlings production. 
The objective of this work was to determine the optimal permanence time for black Brazilian cherry tree minicuttings in plastic bags during rooting, to optimize the use of this type of installation, minimizing the risks of diseases, and obtaining quality seedlings.

\section{MATERIALS AND METHODS}

The experiment was conducted in the Fruit Tree Plants Propagation Laboratory growth room of the Federal University of Pelotas Campus Plant Science Department, in the county of Capão do Leão, RS, from August 2012 to October 2012. The growth room is kept at the constant temperature of $25 \pm 2^{\circ} \mathrm{C}$ and artificial luminosity by cold white fluorescent lamps, with photoperiod of 16 hours and photons flow density of $27 u \mathrm{~mol} \mathrm{~m}^{2} \mathrm{~s}^{-1}$.

The study adopted an entirely randomized experimental design with four replications, each replication composed of five minicuttings, a total of 20 per treatment and eight evaluations, one per week, for a period of two months (7, 14, 21, 28, 35, 42, 49 and 56 days).

Black Brazilian cherry tree (Eugenia uniflora L) seedlings from the Embrapa Center for Temperate Climate Agricultural Research were previously acclimated using the soilless cultivation system, in $20 \mathrm{~cm} \times 12 \mathrm{~cm} \times 75 \mathrm{~cm}$ flower boxes, with a volume of $18 \mathrm{~L}$. The flower box was filled with a layer of construction sand of medium granulometry, previously washed with running water before seedlings installation. In this system, each flower box was irrigated daily with nutrient solution (around $1 \mathrm{~L}$ ). Sand was washed with rainwater, every fifteen days, to prevent salinization.

The nutrient solution used in the parent plants system was formulated by Schuch and Peil (2012), according to the needs of the arrack nut tree, and also used with the Brazilian cherry tree, for being from the same Myrtaceae family. Nutrient solution preparation included rainwater and the following fertilizers and products: calcium nitrate, ammonium nitrate, monopotassium phosphate, potassium sulfate, ammonium sulfate, magnesium sulfate, boric acid, copper sulfate, iron sulfate, Na-EDTA, manganese sulfate, zinc sulfate and sodium molybdate. The $\mathrm{pH}$ was kept between 5.5 and 6.0 and electrical conductivity (CE) was $1.3 \mathrm{dS} \mathrm{m}^{-1}$.

Next, cutting size was standardized between 5 and $7 \mathrm{~cm}$ long, with two half leaves, and lesions were made on the base for IAB immersion for 10 seconds at the concentration of $2.000 \mathrm{mg} . \mathrm{L}^{-1}$ and placed in $22 \mathrm{x} 14 \mathrm{x} 10 \mathrm{~cm}$ plastic boxes with commercial vermiculite substrate. The fungicide Orthocide ${ }^{\circledR}$ was applied during the experiment installation, since, with the microclimate provided by the plastic boxes high humidity, the proliferation off fungi may occur in the minicuttings.

The following variables were analyzed: number of minicuttings with root primordia (intumescence and white spots in the lesion made on the base), rooting percentage, number roots, root length and roots longer than $1 \mathrm{~cm}$.

Data were analyzed in regards to normality by the Shapiro-Wilk test and homocedascity by the Hartley test and residues independence was verified graphically. Then, they were submitted to an analysis of variance $(p \leq 0.05)$. Based on the statistical significance, cultivar effects were evaluated by the Tukey test $(\mathrm{p} \leq 0.05)$. A regression analysis was realized for the days of evaluation factor to choose the best data adjustment, based on the significance and regression coefficient.

\section{RESULTS AND DISCUSSION}

In regards to cultivation time, from the piling moment to the evaluations realized throughout the experiment, and based on the polynomial regression, it was possible to attest the peculiarities of the rooting process and that the Brazilian cherry tree minicuttings rooting speed was fast.

According to (Figure 1A), 1.75 minicuttings were swollen and with white spots from the second week onwards, indicating the beginning of root primordia (Figures $2 \mathrm{~A}$ and $2 \mathrm{~B}$ ).

On the fourth week, 2.75 roots per minicutting were longer than $1 \mathrm{~cm}$, on the seventh, the average was five roots; thus all minicuttings had roots longer than $1 \mathrm{~cm}$ (Figure 1B). However, in a study conducted by Silva et al. (2012), using the Arbequina, Ascolano 315 and MGS GRAP541 olive tree cultivars, the average number was 6, 7.7 and 11 roots, respectively.

On the third week, $70 \%$ of the minicuttings showed rooting (Figure 4) while on the seventh week, $100 \%$ of them showed roots. In an experiment to determine optimal time for the rooting of Eucalyptus spp clones, Ferreira et al. (2004) found the highest rooting percentage of $82.16 \%$ no in the period between 20 and 30 days. Results from the experiment with Brazilian cherry tree, the minicuttings showed $100 \%$ of rooting on the seventh week or 49 days (Figure 3A), reaching maximum rooting potential, making their transplantation to plastic bags possible, developing a new seedling.

It is important to highlight that, although there was no difference in the Brazilian cherry tree minicuttings survival percentage, $100 \%$ of the material survived until the end of the experiment, which is difficult to happen in several vegetative propagation cases and cultures. Similarly, Altoé and Marinho (2012) found survival over $90 \%$ for 'Paluma' guava tree minicuttings 62 days after piling.

The observation of the exact point during which rooting maximum speed takes place may be used as a criterion for removing the minicuttings from the greenhouse. However, the biological aspect must be considered, since a recently rooted minicutting lacks the necessary conditions to develop under adverse environments regarding humidity and temperature, which are more controlled inside acclimatized greenhouses (Melo 2009). 

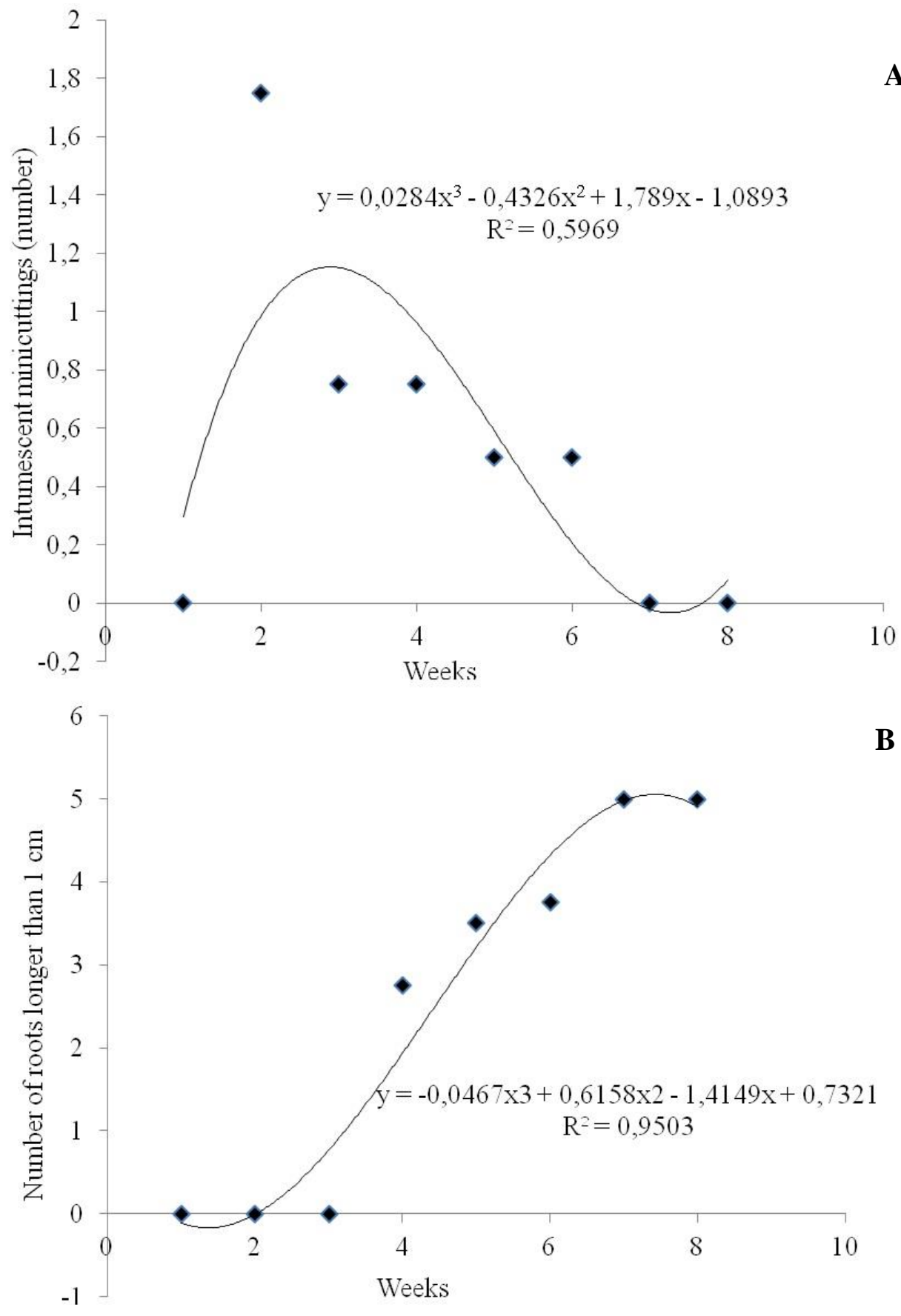

Figure 1. (A) Means for the intumescent minicuttings variables and (B) roots longer than $1 \mathrm{~cm}$ in relation to cultivation time. UFPel/FAEM, Pelotas. 2012.

The number of roots variable showed lack of uniformity in the data during cultivation time. Reaching the eighth week with an average of 2.25 roots per minicutting (Figure $5 \mathrm{~A}$ ).

In regards to root length, roots with an average of $1.4 \mathrm{~cm}$ were found on the fourth week, and, on the seventh week, rooting percentage was $100 \%$ and roots average size was $4.22 \mathrm{~cm}$. On the eight week, the increase in size was small, with an average of $4.58 \mathrm{~cm}$, considering that, in this study, roots of up to $9 \mathrm{~cm}$ were evaluated (Figure 5B). 


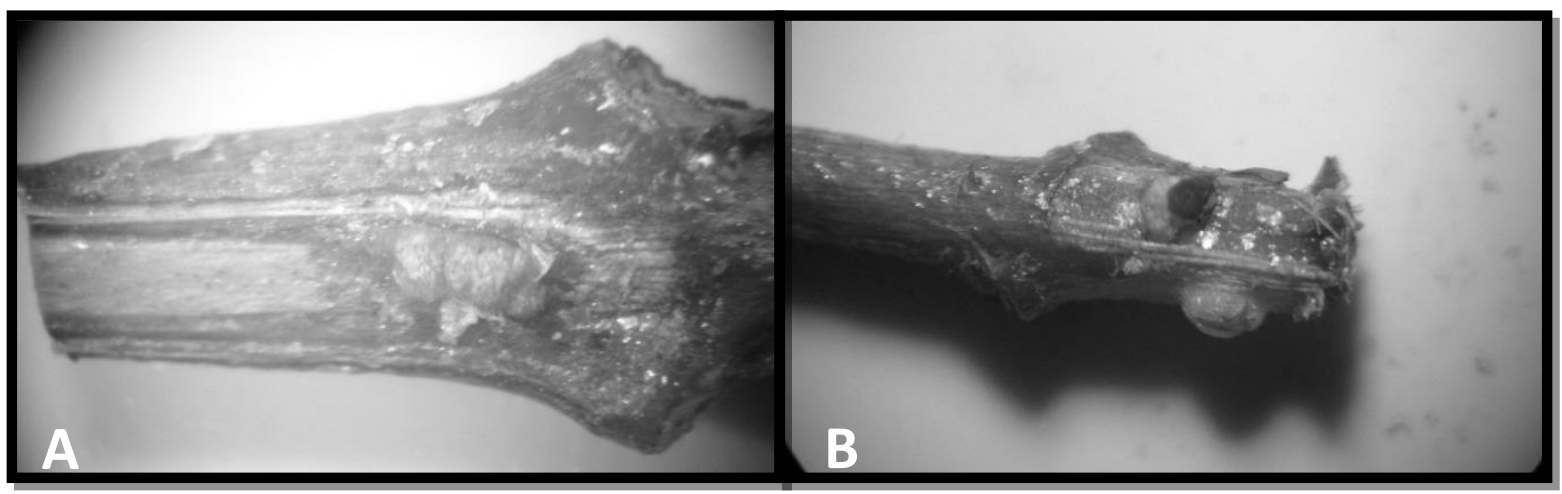

Figure 2. Root primordia indication. (A) swelled minicuttings (B) minicuttings with white spots. UFPel/FAEM, Pelotas. 2012.

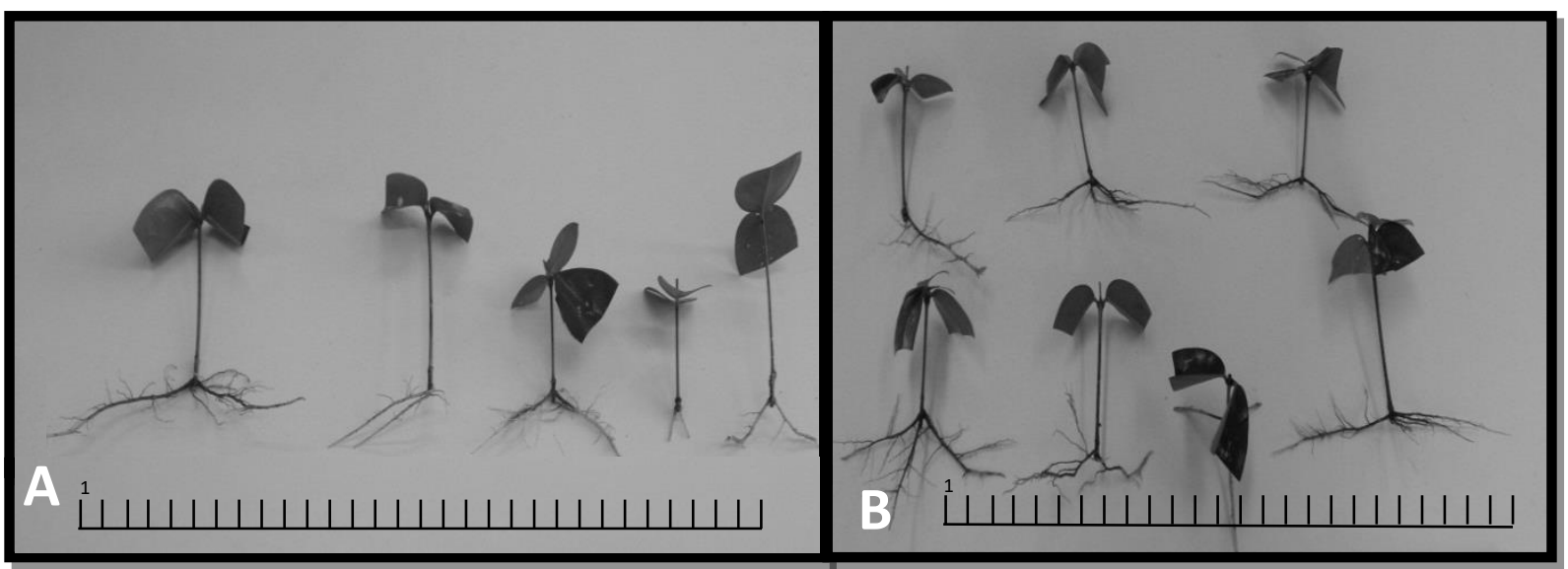

Figure 3. Rooted Brazilian cherry tree minicuttings: (A) seventh evaluation, (B) eighth evaluation. UFPel/FAEM, Pelotas, 2012.

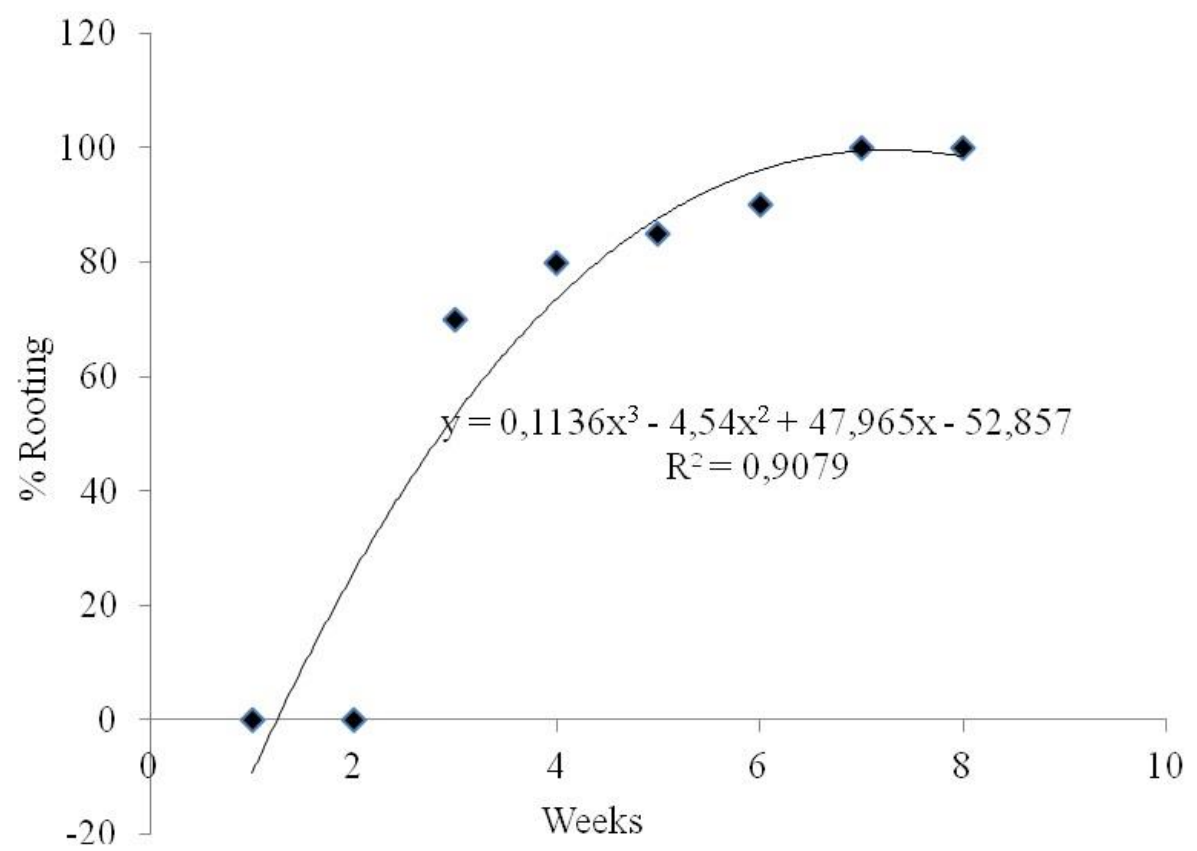

Figure 4. Rooting percentage for Brazilian cherry tree minicuttings in regards to cultivation time. UFPel/FAEM, Pelotas. 2012. 

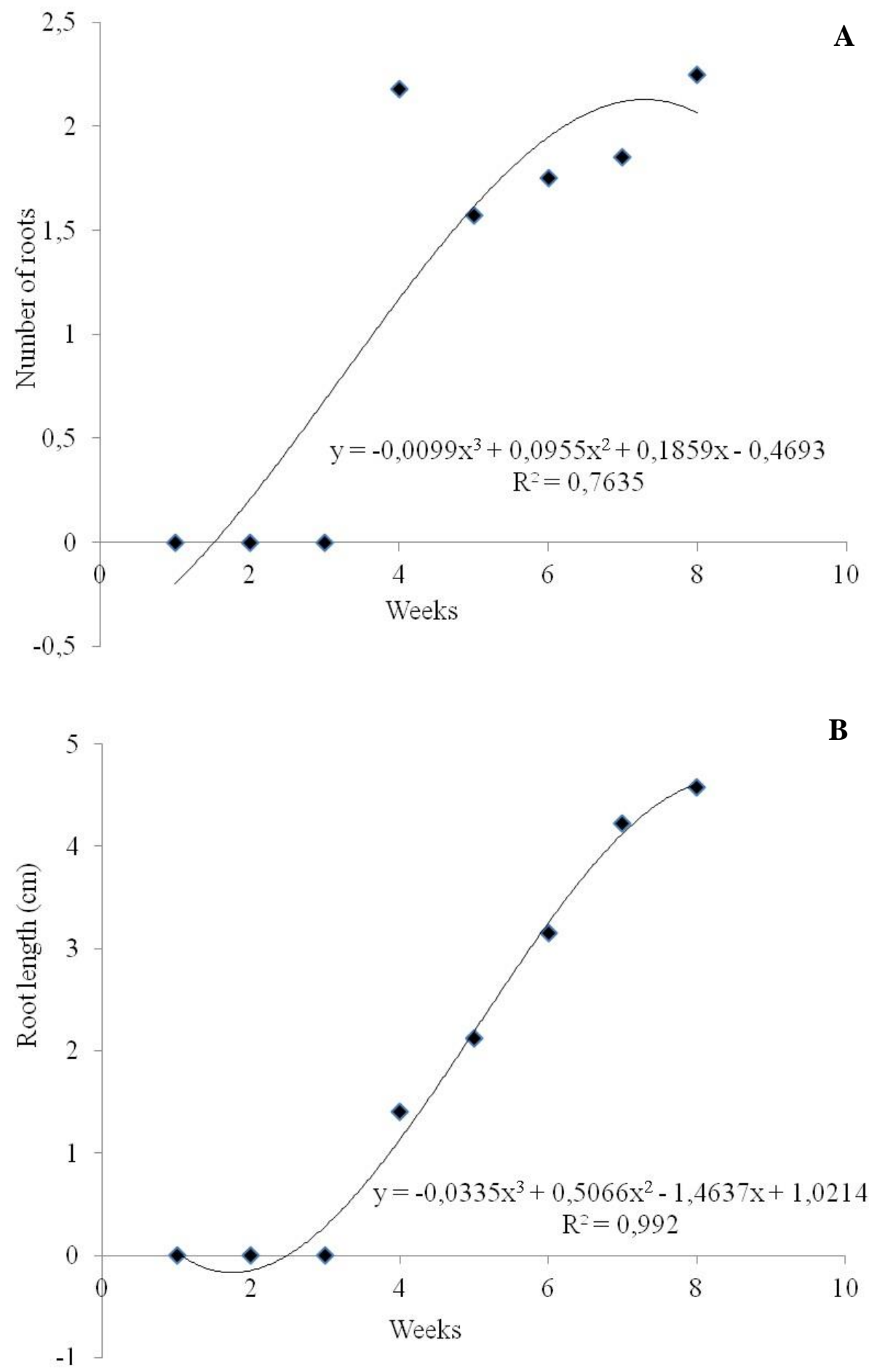

Figure 5. Means for number of roots $(\mathrm{A})$ and root length $(\mathrm{cm})$ variables $(\mathrm{B})$ of Brazilian cherry tree minicuttings in regards to cultivation time. UFPel/FAEM, Pelotas. 2012.

\section{CONCLUSION}

The minicuttings showed gradual rooting increase according to cultivation time. Under experimental conditions, in seven weeks' time, minicuttings are ready to be placed in plastic bags to develop quality seedlings.

\section{REFERENCES}

Alfenas AC, Zauza EAV, Mafia RG and Assis TF (2004) Clonagem e doenças do eucalipto. UFV, Viçosa, $422 p$. 
Altoé JA and Marinho CS (2012) Miniestaquia seriada na propagação da goiabeira 'Paluma'. Revista Brasileira de Fruticultura 34(2): 576-580.

Biasi LA (1996) Emprego do estiolamento na propagação de plantas. Ciência Rural, 26(2): 309-315.

Cappellaro TH (2013) Produção de mudas de oliveira em sistemas de cultivo sem solo. Tese de Doutorado, Faculdade de Agronomia Eliseu Maciel, Universidade Federal de Pelotas.

Carvalho RIN, Silva ID and Faquim R (2007) Enraizamento de miniestacas herbáceas de maracujazeiro amarelo. Semina: Ciências Agrárias 28(3): 387-392.

Fachinello JC, Hoffmann A, Nachtigal JC, Kersten E and Fortes GRL (1995) Propagação de plantas frutíferas de clima temperado. (2. ed). UFPel, Pelotas, 178 p.

Ferrari MP, Grossi F and Wendling I (2004) Propagação vegetativa de espécies florestais. Documento, 94. Embrapa Florestas, Colombo, 22p.

Ferreira EM, Alfenas AC, Mafia RG, Leite HG, Sartório RC and Penchel Filho RM (2004) Determinação do tempo ótimo do enraizamento de miniestacas de clones de Eucalyptus spp. Revista Árvore 28 :183-187.

Figueirêdo GRG; Vilasboas FS, Oliveira, SJR, Sodré GA and Sacramento CK (2013) Propagação da gravioleira por miniestaquia. Revista Brasileira de Fruticultura 35(3): 860-865.

Hartmann HT, Kester DE, Davies Junior FT and Geneve RL (2002) Plant propagation: principles and practices. (7.ed). Prentice-Hall, New Jersey, 880p.

Mayer NA (2001) Propagação assexuada do porta-enxerto umezeiro (Prunus mume Sieb e Zucc.) por estacas herbáceas.. Dissertação de Mestrado em Produção Vegetal, Faculdade de Ciências Agrárias e Veterinárias, Universidade Estadual Paulista.

Melo LA (2009) Armazenamento, aplicação de antioxidantes e otimização do tempo em casa de vegetação no enraizamento de miniestacas de híbridos de Eucalyptus grandis. Dissertação de Mestrado em Ciência Florestal, Universidade Federal de Viçosa.

Pio R, Bastos DC, Berti AJ, Filho JAS, Filho FAAM, Entelmann FA, Alves ASR and Neto JEB (2005) Enraizamento de diferentes tipos de estacas de oliveira (Olea europaea) Utilizando ácido indolbutírico. Ciência e agrotecnologia 29 (3): 562-567.

Scalon SPQ, Scalon Filho H, Rigoni MR and Veraldo F (2001) Germinação e crescimento de mudas de pitangueira (Eugenia uniflora L.) sob condições de sombreamento. Revista Brasileira de Fruticultura 23(3): 652655.

Schuch MW and Peil RMN (2012) Soilless cultivation systems: A new approach in fruit plants propagation in the south of Brazil. Acta Horticulturae 952: 877-883.

Silva LFO, Oliveira AF, Pio R, Zambon CR and Oliveira DL (2012) Enraizamento de estacas semilenhosas de cultivares de oliveira. Bragantia 71(4): 488-492.

Tomaz ZFP, Schuch MW, Peil RMN and Timm CRF (2014) Desenvolvimento de porta-enxertos de pessegueiro obtidos de miniestacas, em duas épocas, e sistema de cultivo sem solo. Revista Brasileira de Fruticultura 36(4): 988-995.

Tonietto A, Fortes GRL and Silva JB (2001) Enraizamento de miniestacas de ameixeira. Revista Brasileira de Fruticultura 23(3): 643-646.

Received: December 22, 2017. 